\title{
Reinfusion of ascites during hemodialysis as a treatment of massive refractory ascites and acute renal failure
}

This article was published in the following Dove Press journal: International Journal of Nephrology and Renovascular Disease I February 201 |

Number of times this article has been viewed

\author{
Ta-Wei Hsu' \\ Yi-Chuan Chen² \\ Meei-Ju Wu² \\ Anna Fen-Yau Li ${ }^{3}$ \\ Wu-Chang Yang ${ }^{2}$ \\ Yee-Yung $\mathrm{Ng}^{2}$ \\ 'Department of Medicine, I-Lan \\ Hospital, ${ }^{2}$ Division of Nephrology, \\ Department of Medicine, ${ }^{3}$ Department \\ of Pathology, Taipei Veterans General \\ Hospital, School of Medicine, National \\ Yang-Ming University, Taipei, Taiwan
}

\begin{abstract}
Refractory ascites can occur in patients with various conditions. Although several procedures based on the reinfusion of ascitic fluid have been reported after the failure of bed rest, salt and water restriction, diuretics, intravenous administration of albumin, and repeated paracentesis, these procedures are performed for ascitic fluid removal without dialytic effect. In this study, a flow control reinfusion of ascites during hemodialysis (HD) was performed to demonstrate the efficacy of this method in a lupus patient with massive refractory ascites and respiratory and acute renal failure (ARF). The alleviation of ascites and ARF attests to the success of the flow control reinfusion of ascites during HD. This procedure can control the rate of ascites and body fluid removal simultaneously during HD using the roller pump. In conclusion, with a normal coagulation profile, the procedure of flow control reinfusion of ascites during HD is an effective alternative treatment for the alleviation of refractory ascites with renal failure.
\end{abstract}

Keywords: ascites, lupus, renal failure, reinfusion

\section{Introduction}

Refractory ascites can occur in patients with conditions such as liver cirrhosis, congestive heart failure, nephrotic syndrome, and lupus serositis ${ }^{1}$ and in many cases cause abdominal discomfort and respiratory distress to the patient. The treatments for refractory ascites, eg, bed rest, salt and water restriction, diuretics, intravenous administration of albumin, and repeated paracentesis, are usually unsatisfactory. Several procedures based on the reinfusion of ascitic fluid have been performed for ascitic fluid removal..$^{2-8}$ This report introduces the procedure flow control reinfusion of ascites into the dialyzer during hemodialysis (HD) (Figure 1A), by which a 34-year-old lupus patient with massive ascites, respiratory distress, and acute renal failure (ARF), who did not respond to diuretics, repeated paracentesis with intravenous albumin infusion, and HD, was successfully treated. Prophylactic fresh frozen plasma infusion, sequential ultrafiltration, and reduced dialysate temperature during HD in previous treatments did not prevent intradialytic hypotension. The patient's symptoms were remedied by seven sessions of flow control reinfusion of ascites during HD (Figure 1B, C).

\section{Case}

A 34-year-old female with systemic lupus erythematosus was admitted due to progressive lower leg edema, massive ascites, and nausea after treatment of bed rest, salt and water restriction, diuretics, intravenous administration of albumin and methylprednisolone, and repeated paracentesis for 2 months. On physical examination, her blood pressure was $127 / 82 \mathrm{~mm} \mathrm{Hg}$, pulse rate 84 beats/min, respiratory rate 
A

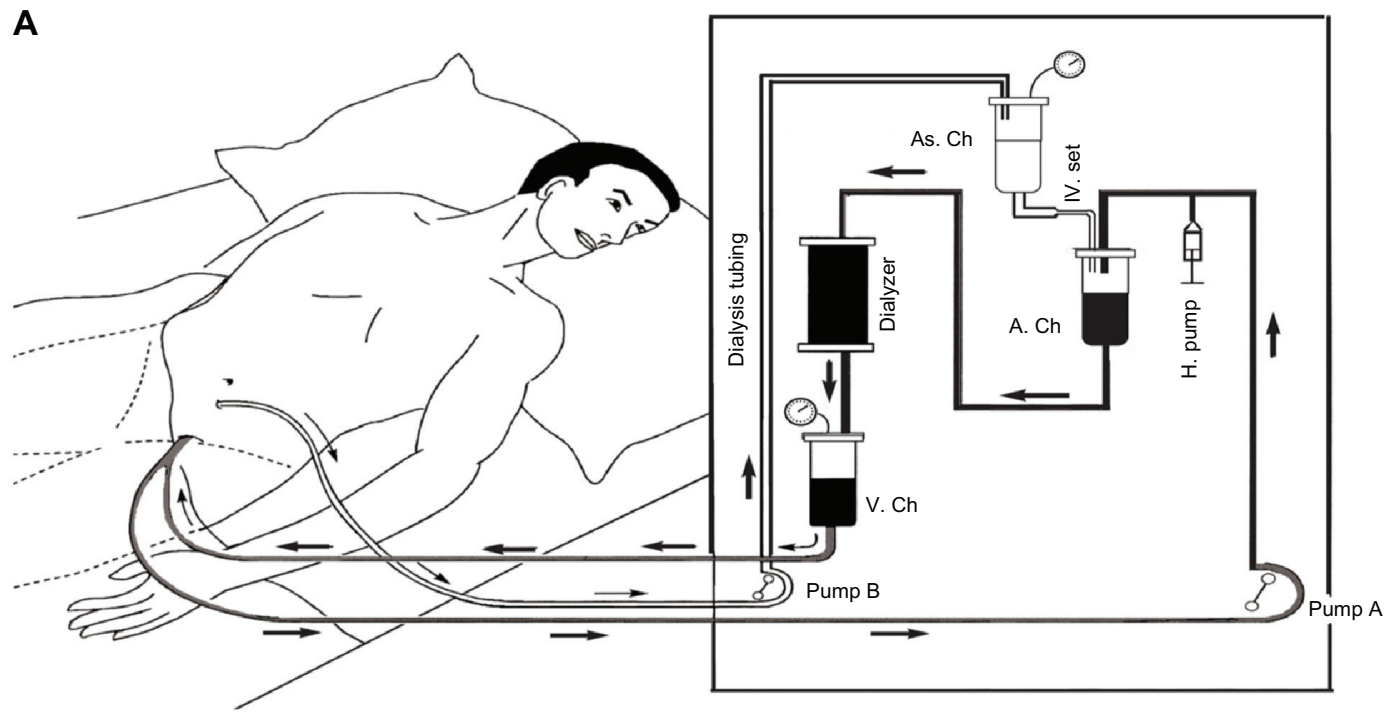

B

C

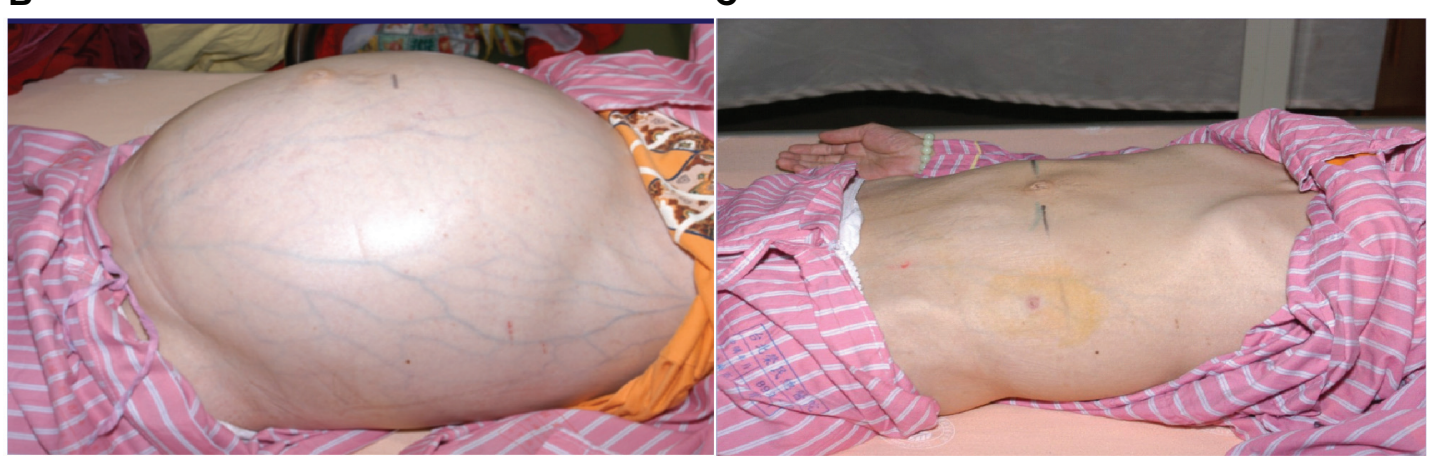

Figure I A) A paracentesis pigtail catheter was inserted into the abdominal cavity to draw out the ascites into the arterial chamber to be mixed with the blood by the flow control roller pump (pump B) during hemodialysis. This procedure allows for control of the flow of ascite reinfusion by the flow control roller pump (pump B) and the amount of body fluid removal by the ultrafiltration rate of the dialyzer simultaneously. B) The abdomen was distended by massive ascites. The superficial veins were also engorged before continuous infusion of ascites into the dialyzer to mix with blood. C) After ascite removal by ascite reinfusion into dialyzer, the distended abdomen and engorged veins disappeared.

Abbreviations: H. pump, heparin pump; IV. set, intravenous set; A. Ch, arterial chamber; As. Ch, ascites chamber; V. Ch, venous chamber.

20 breaths/min, and body temperature $37^{\circ} \mathrm{C}$. Her abdomen was markedly distended and her lower extremities were severely edematous. The results obtained in laboratory investigations were as follows: white blood cells (WBCs) $5.8 \times 10^{9} / \mathrm{L}$ (normal range $4.5-11 \times 10^{9} / \mathrm{L}$ ), hemoglobin $89 \mathrm{~g} / \mathrm{L}$ (normal range $120-160 \mathrm{~g} / \mathrm{L}$ ), platelets $220 \times 10^{9} / \mathrm{L}$ (normal range 150-350 $\times 10^{9} / \mathrm{L}$ ), serum blood urea nitrogen (BUN) $13.5 \mathrm{mmol} / \mathrm{L}$ (normal range $2.5-7 \mathrm{mmol} / \mathrm{L}$ ), creatinine $170 \mu \mathrm{mol} / \mathrm{L}$ (normal range $50-110 \mu \mathrm{mol} / \mathrm{L}$ ), albumin $19 \mathrm{~g} / \mathrm{L}$ (normal range $37-53 \mathrm{~g} / \mathrm{L}$ ), alanine aminotransferase $0.24 \mu \mathrm{kat} / \mathrm{L}$ (normal range $0-0.66 \mu \mathrm{kat} / \mathrm{L}$ ), aspartate aminotransferase $0.60 \mu \mathrm{kat} / \mathrm{L}$ (normal range $0.08-0.76 \mu \mathrm{kat} / \mathrm{L}$ ), C-reactive protein $0.286 \mathrm{mg} / \mathrm{dL}$ (normal range $0-0.5 \mathrm{mg} / \mathrm{dL}$ ), complement 3 (C3) $0.4 \mathrm{~g} / \mathrm{L}$ (normal range $0.8-1.5 \mathrm{~g} / \mathrm{L}$ ), complement 4 (C4) $0.1 \mathrm{~g} / \mathrm{L}$ (normal range $0.2-0.4 \mathrm{~g} / \mathrm{L}$ ), and double-strand DNA (dsDNA) $263 \mathrm{IU} / \mathrm{mL}$ (normal range $<30 \mathrm{IU} / \mathrm{mL}$ ). Urine protein excretion was $4.86 \mathrm{~g} /$ day.
Chest X-ray showed massive bilateral pleural effusion. The WBC count of ascitic fluid was $10 / \mathrm{mm}^{3}$. The serum-ascites albumin gradient was $1.4 \mathrm{mg} / \mathrm{dL}$. The results of bacteria culture, acid-fast stain, malignant cell, and tuberculosispolymerase chain reaction of ascites were negative. The Doppler of the main portal vein, inferior vena cava, major portal branches, and hepatic vein were patent without obstruction. The abdominal computed tomography scan revealed massive ascites (Figure 2A). The echocardiogram showed no pericardial effusion and preserved left ventricle systolic function. Unfortunately, progressive massive ascite accumulation gave rise to breathing difficulty and decreased urine output, despite an increase in serum albumin from $19 \mathrm{~g} / \mathrm{L}$ to $28 \mathrm{~g} / \mathrm{L}$ after the aforementioned treatments for 1 month at the hospital. The serum BUN and creatinine levels were increased to $30.5 \mathrm{mmol} / \mathrm{L}$ and $720 \mu \mathrm{mol} / \mathrm{L}$ from $13.5 \mathrm{mmol} / \mathrm{L}$ and $170 \mu \mathrm{mol} / \mathrm{L}$, respectively. Disseminated intravascular 
A

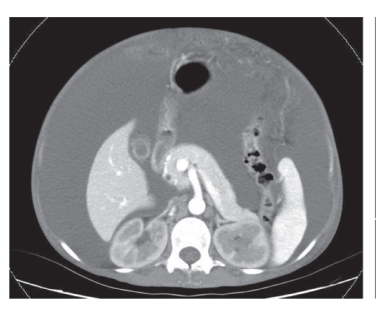

B

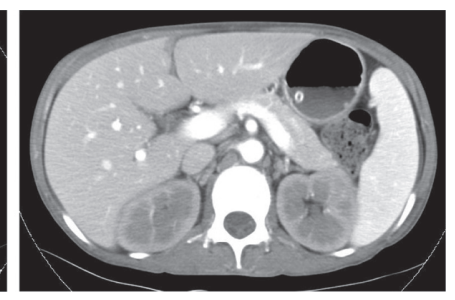

Figure 2 A) Contrast-enhanced CT of abdomen revealed massive ascites. B) Contrast-enhanced CT taken after modified hemodialysis for 10 days. The scan at the same level as (A) reveals the disappearance of ascites.

Abbreviation: $\mathrm{CT}$, computed tomography.

coagulation (DIC) was within a normal range. Her lupus activity did not respond to plasma exchange, methylprednisolone $1000 \mathrm{mg}$ pulse therapy, oral prednisolone $60 \mathrm{mg}$ daily, or cyclosporine $100 \mathrm{mg}$ twice daily. Her renal failure, leg edema, and refractory ascites could not be controlled by HD due to frequent intradialytic hypotension, which could not be corrected by prophylactic fresh frozen plasma infusion, sequential ultrafiltration, and reduction in dialysate temperature during HD. Therefore, continuous flow control reinfusion of ascites into a dialyzer during $\mathrm{HD}$ was designed to alleviate the ascites. A paracentesis pigtail catheter was inserted into the abdominal cavity and connected to a sterile three-way stopcock. When ascite reinfusion was planned, a set of dialysis tubing was connected with the sterile three-way stopcock to draw out the ascites at the speed of $12-15 \mathrm{~mL} / \mathrm{min}$ ( $720-900 \mathrm{~mL} / \mathrm{h}$ ) into the dialyzer to mix with the blood by the roller pump during HD. The mixed blood and ascites were then channeled into the systemic circulation during a 4-hour HD session (Figure 1A). The ultrafiltration rate of the dialyzer was maintained at around $1 \mathrm{~L} / \mathrm{h}$ to allow fluid removal from the blood and infused ascites in each 4-hour HD session. After seven sessions of continuous reinfusion of ascites into the dialyzer during HD, $\sim 20 \mathrm{~L}$ of ascites were drawn out. The body weight and abdominal girth decreased from $50.2 \mathrm{~kg}$ to $37 \mathrm{~kg}$ and from $92 \mathrm{~cm}$ to $72 \mathrm{~cm}$, respectively (Figure 3). The serum albumin level increased from 30 to $35 \mathrm{~g} / \mathrm{L}$ (Figure 3). There was no intradialytic hypotension, fever, gastrointestinal bleeding, or DIC. Her respiratory distress and general condition also improved after the procedures. The levels of complements $\mathrm{C} 3$ and $\mathrm{C} 4$ also increased from $0.4 \mathrm{~g} / \mathrm{dL}$ to $0.7 \mathrm{~g} / \mathrm{dL}$ and from $0.1 \mathrm{~g} / \mathrm{dL}$ to $0.13 \mathrm{~g} / \mathrm{dL}$, respectively. After the ascites subsided, the paracentesis pigtail catheter was removed. A piece of omentum was obtained by peritoneoscopy for the evaluation of the cause of refractory ascites. The pathologic finding of the omentum was chronic inflammation with cell infiltration, congestion, and fibrosis (Figure 4).

In the following 60 months, the serum creatinine level was around $120 \mu \mathrm{mol} / \mathrm{L}$ on immunosuppressive agents. There were no further episodes of refractory ascites. The patient also had an increase in muscle mass.

\section{Discussion}

In our patient, liver cirrhosis, congestive heart failure, carcinomatous peritonitis, and bacterial peritonitis-related ascites were excluded by serial examinations. The refractory ascites

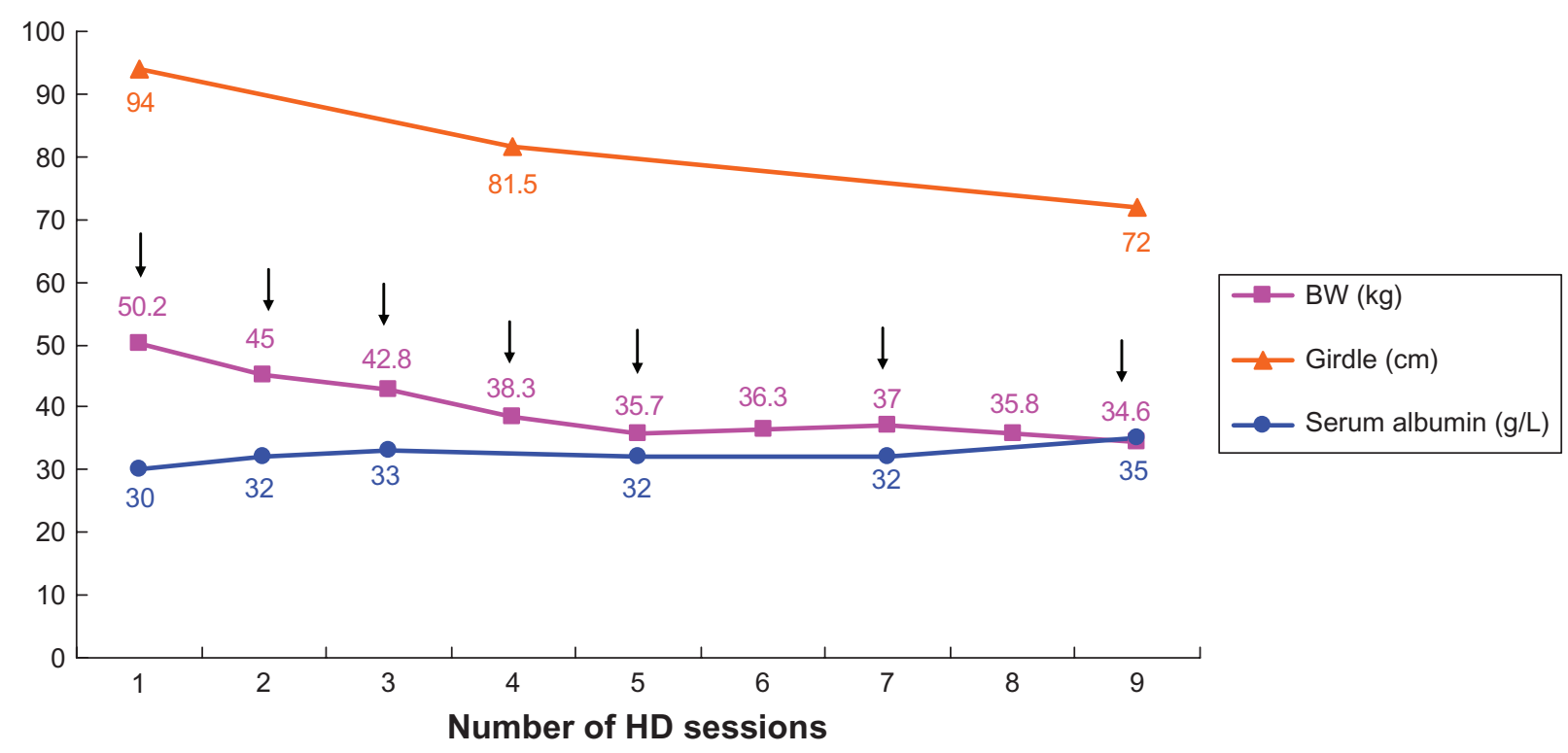

Figure 3 The changes in body weight, abdominal girdle, and serum albumin after seven sessions of continuous infusion of ascites into the dialyzer during hemodialysis over 9 days.

Abbreviation: BW, body weight; HD, hemodialysis. 


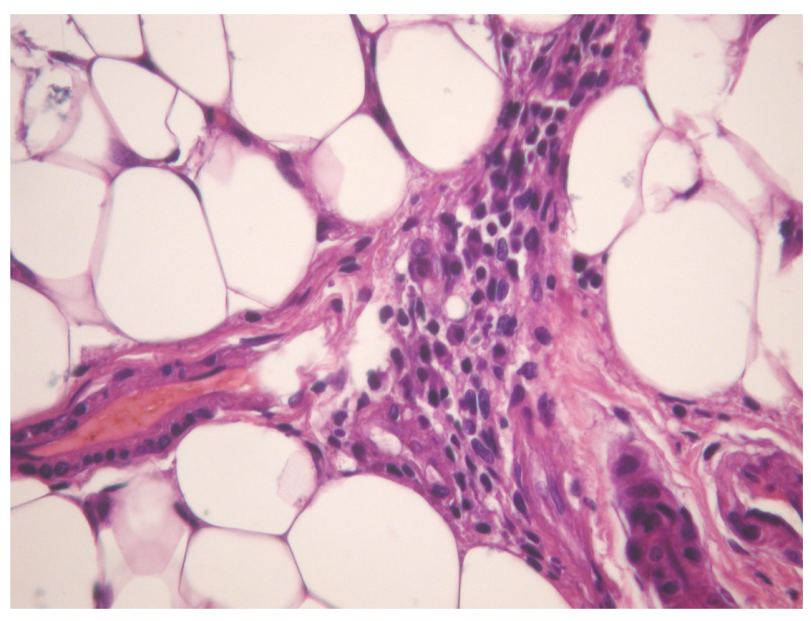

Figure 4 An omentum biopsy shows chronic inflammatory cell infiltration and congestion.

caused by lupus serositis was most likely due to the high level of dsDNA, low serum level of $\mathrm{C} 3 / \mathrm{C} 4$, and inflammatory omentum (Figure 4).

The patient's refractory ascites, leg edema, and respiratory distress improved after seven sessions of continuous infusion of ascites into the dialyzer during HD after failure of other treatments, including bed rest, salt and water restriction, diuretics, intravenous administration of albumin, repeated paracentesis, sequential ultrafiltration, and reduced dialysate temperature during HD. The success of this treatment showed that the removed body fluid was replaced by the drawn out ascites at a speed of 12-15 mL/min (720-900 mL/h) concurrently during HD while ultrafiltration was set at around $1 \mathrm{~L} / \mathrm{h}$. There were 2.88-3.6 L of ascitic fluid from the abdomen infused into the dialyzer and a net $0.4-1.12 \mathrm{~L}$ of fluid removed from the systemic circulation during each 4-hour HD session. A serum albumin level increase from $28 \mathrm{~g} / \mathrm{L}$ to $35 \mathrm{~g} / \mathrm{L}$ after seven sessions of continuous reinfusion was due to the infused ascites and protein into the systemic circulation during HD (Figure 3). The increase in serum level of albumin might have also pulled the interstitial fluid into the intravascular space via the increase in serum oncotic pressure..$^{5,7}$ Leg edema, pleural effusion, and refractory ascites were ameliorated by small negative fluid balance and increased serum albumin level during HD.

In this case, ARF occurred, along with the progressively worsening ascites and respiratory distress, but improved after the refractory ascites subsided. This implied that ARF was mostly related to the refractory ascite-induced hypovolemia and unstable hemodynamic status.

Ascite reinfusion has been reported in chronic HD patients with cirrhotic, lupus, or nephrogenic ascites. ${ }^{2-8,10-13}$
In this case, ascitic fluid was infused into the dialyzer under flow control by the roller pump, and the fluid was removed from the systemic circulation simultaneously during HD. This procedure of flow control allowed adequate fluid removal without intradialytic hypotension.

Several procedures based on the reinfusion of ascitic fluid have been reported in chronic HD patients with cirrhotic, lupus, or nephrogenic ascites, eg, intravenous reinfusion of concentrated ascites, extracorporeal ultrafiltration of ascite fluid with peritoneal reinfusion, ascitic fluid concentration with blood reinfusion during HD, and peritoneovenous shunt..$^{2-8,10-13}$ In comparison with those procedures, the flow control reinfusion of ascites during HD is rapid, easier, and effective. Ascitic fluid does not need to be concentrated before reinfusion. This procedure and McGill et al's method ${ }^{13}$ could simultaneously control the flow of ascite reinfusion by the flow control roller pump and the amount of body fluid removal by the ultrafiltration rate of dialyzer. The serum albumin level was increased after the infusion of protein-rich ascites into the systemic circulation during HD. The elevated serum level of albumin pulls the interstitial fluid into the intravascular space via increased serum oncotic pressure.

With the successful outcome of this case report, we believe that flow control reinfusion of ascites during HD is an effective alternative treatment for the alleviation of refractory ascites in patients with renal failure, who are unresponsive to bed rest, salt and water restriction, diuretics, intravenous administration of albumin, repeated paracentesis, sequential ultrafiltration, and reduced dialysate temperature during HD. Although not observed in this case, the potential adverse effects, such as fever, gastrointestinal bleeding, DIC, peritonitis, or septicemia, by the intravenous or intra-abdominal infusion of ascites should be kept in mind. ${ }^{14,15}$ The activation of fibrinolytic activity of ascites due to the relative plasminogen activator inhibitor type-1 deficiency and enhanced basal tissue plasminogen activator has been reported. ${ }^{16-19}$ Therefore, clotting tests should be carried out before the procedure is initiated, and if the patient's blood and ascites denote a fibrinolytic activity, the procedure should be considered hazardous and probably contraindicated.

In conclusion, the alleviation of ascites and ARF attest to the success of the procedure of continuous infusion of ascites into the dialyzer during HD. With normal coagulation function, it is an effective alternative treatment of refractory ascites, especially in patients with renal failure or who are unresponsive to bed rest, salt and water restriction, diuretics, intravenous administration of albumin, repeated paracentesis, 
sequential ultrafiltration, and reduced dialysate temperature during HD.

\section{Acknowledgments}

This case report was supported by a grant (NSC 96-2314B-075-020-MY3, NSC96-2314-B-010-028-MY2) from the National Science Council and by the Szu-Yuan Research Foundation of Internal Medicine, Republic of China. We thank Dr Sandy Cho and Ming-Yu Lai for providing valuable suggestions and English correction.

\section{Disclosure}

The authors report no conflicts of interest in this work.

\section{References}

1. Wilkins KW Jr, Hoffman GS. Massive ascites in systemic lupus erythematosus. J Rheumatol. 1985;12(3):571-574.

2. Okada K, Takahashi S, Higuchi T, Maeda H. Long-term effect of intravenous reinfusion of unmodified autogenous peritoneal fluid combined with hemodialysis in a patient with dialysis-related ascites. Nephron. 1993;65(3):474-475.

3. Bruno S, Borzio M, Romagnoni M, et al. Comparison of spontaneous ascites filtration and reinfusion with total paracentesis with intravenous albumin infusion in cirrhotic patients with tense ascites. BMJ. 1992; 304(6843):1655-1658.

4. Albalate M, López García MD, Vázquez A, et al. Concentrated ascitic fluid reinfusion in cirrhotic patients: a simplified method. Am J Kidney Dis. 1997;29(3):392-398.

5. Daimon S, Yasuhara S, Saga T, Tokunaga S, Chikaki H, Dan K. Efficacy of extracorporeal ultrafiltration of ascitic fluid as a treatment of refractory ascites. Nephrol Dial Transplant. 1998;13(10):2617-2623.

6. Hwang JC, Chen JA, Fung HY. Hemodialysis alternative with ascites ultrafiltration for an end-stage renal failure patient associated with tense ascites secondary to decompensated liver cirrhosis. Am J Kidney Dis. 1996;28(6):899-903.
7. Catalano C, Fabbian F, di Landro D. Reinfusion and concentration of ascitic fluid during hemodialysis in a cirrhotic uremic patient. Am J Kidney Dis. 1998;32(1):164-167.

8. Leveen HH, Christoudias G, Ip M, Luft R, Falk G, Grosberg S. Peritoneo-venous shunting for ascites. Ann Surg. 1974;180(4): 580-591.

9. Nicholls AJ, Platts MM, Triger DR. Regular reinfusion of ascites during haemodialysis in a patient with amyloidosis. Br Med J (Clin Res Ed). 1983;287(6394):726.

10. Asakimori Y, Yorioka N, Kumagai J, Kawanishi H, Tsuchiya $\mathrm{S}$. Direct infusion of ascites into the blood circuit during hemodiafiltration in uremic patients with cirrhosis. Int J Artif Organs. 2000;23(4):232-236.

11. Liu J, Zhang C, Zhu X, Shang S, Li W, Gu Q. Intravenous infusion ascitic fluid during hemodialysis: a study of 108 treatments in 13 uremic cases. Artif Cells Blood Substit Immobil Biotechnol. 1999;27(2): $153-162$.

12. Touam M, Orozco R, Fumeron C, Ganea A, Drüeke T, Grünfeld JP. [Refractory ascites in hemodialysis: treatment by paracentesis-reinjection during dialysis]. [article in French] Nephrologie. 2001;22(1):25-28.

13. McGill RL, Bakos JR, Marcus RJ. Ascites reinfusion dialysis (ARD) for renal failure with refractory ascites. Clin Nephrol. 2004;62(5): 374-379.

14. Moult PJ, Parbhoo SP, Sherlock S. Clinical experience with the Rhône-Poulenc ascites reinfusion apparatus. Postgrad Med J. 1975;51(598): 574-576.

15. Lévy VG, Opolon P, Pauleau N, Caroli J. Treatment of ascites by reinfusion of concentrated peritoneal fluid-review of 318 procedures in 210 patients. Postgrad Med J. 1975;51(598):564-566.

16. Agarwal S, Joyner KA Jr, Swaim MW. Ascites fluid as a possible origin for hyperfibrinolysis in advanced liver disease. Am J Gastroenterol. 2000;95(11):3218-3224.

17. Buø L, Karlsrud TS, Dyrhaug G, et al. The fibrinolytic system in human ascites. Scand J Gastroenterol. 1995;30(11):1101-1107.

18. Ferguson JW, Helmy A, Ludlam C, Webb DJ, Hayes PC, Newby DC. Hyperfibrinolysis in alcoholic cirrhosis: relative plasminogen activator inhibitor type 1 deficiency. Thromb Res. 2008;121(5): $675-680$.

19. Scott-Coombes DM, Whawell SA, Vipond MN, Crnojevic L, Thompson JN. Fibrinolytic activity of ascites caused by alcoholic cirrhosis and peritoneal malignancy. Gut. 1993;34(8):1120-1122.

\section{Publish your work in this journal}

The International Journal of Nephrology and Renovascular Disease is an international, peer-reviewed open-access journal focusing on the pathophysiology of the kidney and vascular supply. Epidemiology, screening, diagnosis, and treatment interventions are covered as well as basic science, biochemical and immunological studies. The journal welcomes
Dovepress

original research, clinical studies, reviews \& evaluations, expert opinion and commentary, case reports and extended reports. The manuscript management system is completely online and includes a very quick and fair peerreview system, which is all easy to use. Visit http://www.dovepress.com/ testimonials.php to read real quotes from published authors. 